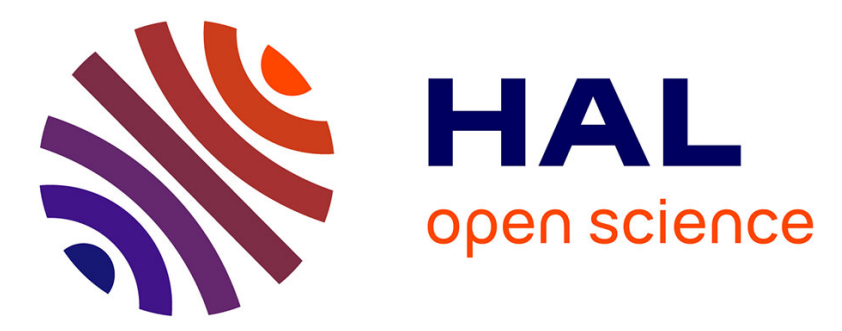

\title{
A first-generation microsatellite linkage map of the Japanese quail
}

B.B. Kayang, Alain Vignal, M. Inoue-Murayama, M. Miwa, Jean Louis

Monvoisin, S. Ito, Francis F. Minvielle

\section{- To cite this version:}

B.B. Kayang, Alain Vignal, M. Inoue-Murayama, M. Miwa, Jean Louis Monvoisin, et al.. A firstgeneration microsatellite linkage map of the Japanese quail. Animal Genetics, 2004, 35, pp.195-200. hal-02674147

\section{HAL Id: hal-02674147 https://hal.inrae.fr/hal-02674147}

Submitted on 31 May 2020

HAL is a multi-disciplinary open access archive for the deposit and dissemination of scientific research documents, whether they are published or not. The documents may come from teaching and research institutions in France or abroad, or from public or private research centers.
L'archive ouverte pluridisciplinaire HAL, est destinée au dépôt et à la diffusion de documents scientifiques de niveau recherche, publiés ou non, émanant des établissements d'enseignement et de recherche français ou étrangers, des laboratoires publics ou privés. 


\title{
A first-generation microsatellite linkage map of the Japanese quail
}

\author{
B. B. Kayang*, A. Vignal* ${ }^{*}$, M. Inoue-Murayama ${ }^{\dagger}$, M. Miwa ${ }^{\dagger}$, J. L. Monvoisin ${ }^{\ddagger}$, S. Ito $^{\dagger}$ \\ and F. Minvielle ${ }^{\ddagger}$
}

*Laboratoire de Génétique Cellulaire, Centre INRA de Toulouse, BP 27 Auzeville, 31326 Castanet Tolosan, France. ${ }^{\dagger}$ Faculty of Agriculture, Gifu University, Gifu 501-1193, Japan. ${ }^{\ddagger}$ UMR Génétique et Diversité Animales, INRA bât 211, 78352 Jouy-en-Josas Cedex, France

\section{Summary}

\begin{abstract}
A linkage map of the Japanese quail (Coturnix japonica) genome was constructed based upon segregation analysis of 72 microsatellite loci in $433 \mathrm{~F}_{2}$ progeny of 10 half-sib families obtained from a cross between two quail lines of different genetic origins. One line was selected for long duration of tonic immobility, a behavioural trait related to fearfulness, while the other was selected based on early egg production. Fifty-eight of the markers were resolved into 12 autosomal linkage groups and a $\mathrm{Z}$ chromosome-specific linkage group, while the remaining 14 markers were unlinked. The linkage groups range from $8 \mathrm{cM}$ (two markers) to $206 \mathrm{cM}$ (16 markers) and cover a total map distance of $576 \mathrm{cM}$ with an average spacing of $10 \mathrm{cM}$ between loci. Through comparative mapping with chicken (Gallus gallus) using orthologous markers, we were able to assign linkage groups CJA01, CJA02, CJA05, CJA06, CJA14 and CJA27 to chromosomes. This map, which is the first in quail based solely on microsatellites, is a major step towards the development of a quality molecular genetic map for this valuable species. It will provide an important framework for further genetic mapping and the identification of quantitative trait loci controlling egg production and fear-related behavioural traits in quail.
\end{abstract}

Keywords chromosomes, genetic map, Japanese quail, linkage groups, microsatellite

\section{Introduction}

The Japanese quail, originally domesticated around the 11th century as a pet song bird (Howes 1964; Crawford 1990), has gained in value as a food animal since 1910 (Wakasugi 1984). Several aspects account for the utility of this bird. First, it has attained economic importance as an agricultural species producing eggs and meat that are enjoyed for their unique flavour. Egg production is paramount in Japan and southeast Asia, while meat is the main product in Europe (Minvielle 1998). Second, the low maintenance cost associated with its small body size (80-300 g) coupled with its short generation interval, resistance to diseases and high egg production, render it an excellent laboratory animal. It has thus been used extensively in many studies including behavioural (Mills \& Faure 1991), developmental (Le Douarin et al. 1997), physiological (Balthazart et al. 2003), genetic (Jones et al. 1991) and

Address for correspondence

Alain Vignal, Laboratoire de Génétique Cellulaire, Centre INRA de Toulouse, BP 27 Auzeville, 31326 Castanet Tolosan, France.

E-mail: vignal@autan.toulouse.inra.fr

Accepted for publication 20 March 2004 biomedical (Ratnamohan 1985) researches. Third, Japanese quail is phylogenetically closely related to the chicken (Stock \& Bunch 1982). Both species have a karyotype of $2 n=78$ chromosomes and a similar genome length of $1.2 \times 10^{9} \mathrm{bp}$, consisting of morphologically distinct macrochromosomes (1-8 and the ZW sex chromosomes) and cytologically indistinguishable microchromosomes. Indeed, recent cytogenetic studies have confirmed the highly conserved chromosome homology between Japanese quail and chicken, revealing only very few chromosome rearrangements after divergence of the two species (Shibusawa et al. 2001). Thus, the Japanese quail has been recommended as a model species for poultry (Baumgartner 1994; Mills et al. 1997).

In poultry, genome research has been concentrated on the chicken, producing a consensus linkage map of nearly 2000 loci (Groenen et al. 2000) through international collaboration. Unfortunately, microsatellites, which are the markers of choice for linkage mapping in animals, occur at about a 5-7-fold lower frequency in avian genomes than in mammals (Primmer et al. 1997), thus limiting the extent to which marker-rich genetic maps can be developed. In addition, the avian microchromosomes, which are indistinguishable and therefore difficult to map cytogenetically, are 
also gene-dense (Smith et al. 2000) and particularly low in microsatellite density (Primmer et al. 1997), thus further compounding the problem. Furthermore, cross-species microsatellite amplification in birds, unlike in mammals, is successful only at a low rate even among closely related species (Pang et al. 1999; Inoue-Murayama et al. 2001), thereby making it difficult to apply markers from a map-rich species. Consequently, mapping is relatively slow in birds, and preliminary genetic maps have only just emerged for the turkey (Burt et al. 2003; Harry et al. 2003) but are yet to be published for most poultry species.

Until recently, marker information in quail was very scanty and only three classical linkage groups based on plumage colour and blood protein markers (Ito et al. 1988a,b; Shibata \& Abe 1996; Minvielle et al. 2000b) were available. But the situation began to change with the development of original microsatellite markers for quail (Kayang et al. 2000, 2002) and the recent publication of the first ever quail genetic map based completely on DNA markers (Roussot et al. 2003). This map, which spans $1516 \mathrm{cM}$ and contains 258 loci assigned to 41 linkage groups (including the sex chromosomes), is comprehensive but consists solely of amplified fragment length polymorphism (AFLP) markers. Due to their biallelic dominant nature, the information content of AFLP markers is lower than that of other marker types, especially microsatellites. Besides, AFLP markers are less suited to total genome scan in large populations. Hence, the AFLP map needs to be enriched with other marker types, particularly genes and microsatellites, to enhance its usefulness. As a step towards the development of a quality genetic map for quail, we performed linkage analysis of 72 microsatellites in 10 half-sib quail families and present here a quail genetic linkage map based completely on microsatellite markers.

\section{Materials and methods}

\section{Japanese quail resource population}

A resource population maintained at the INRA Unité Expérimentale de Génétique Avicole, Nouzilly, France, was used. This population was derived from a cross between two quail lines of different genetic origins (Minvielle et al. 2000a). One line was selected for long duration of tonic immobility (Mills \& Faure 1991), a fear-related behaviour, and the other line was selected for early egg production (Minvielle et al. 2000c). The $\mathrm{F}_{0}$ generation consisted of 12 dams and 12 sires originating from the two lines, and these were reciprocally crossed to produce the $\mathrm{F}_{1}$ offspring. Unrelated $\mathrm{F}_{1}$ matings of 10 males to 30 females generated 10 half-sib families with an average of $43 \mathrm{~F}_{2}$ chicks each. Thus, a total of 497 quails $\left(24 \mathrm{~F}_{0}, 40 \mathrm{~F}_{1}\right.$ and $\left.433 \mathrm{~F}_{2}\right)$ constituted the mapping population from which DNA samples were obtained for genotyping.
The population used for the microsatellite map differed from the AFLP mapping population, which was a cross between two quail lines of the same genetic origin that had been divergently selected for short (STI) or long (LTI) duration of tonic immobility. Although the LTI line was common to both mapping experiments, the $\mathrm{F}_{0}$ from this line used in our study belonged to a more recent generation of unknown parentage to the AFLP mapping population. The microsatellite mapping population, with the early egg production line, was preferred in our study as it also served in a QTL experiment for production traits and fear-related behaviour.

\section{Microsatellite markers}

A total of 103 microsatellite markers were tested of which 100 were original quail microsatellites that had been developed and characterized previously (Kayang et al. 2000, 2002). The remaining three were original chicken markers (ADL0037, ADL0142 and ADL0255) located on chicken chromosomes GGA1, GGA6 and GGA4, respectively, that cross-amplify quail DNA and have been confirmed to be orthologous to the quail loci (Inoue-Murayama et al. 2001).

\section{Analyses of microsatellite markers}

PCR amplifications were carried out on a TAKARA PCR Thermal Cycler (TAKARA Biomedicals, Berkeley, CA, USA) in $15 \mu \mathrm{l}$ reaction mixtures containing $20 \mathrm{ng}$ of the DNA template, $0.3 \mu \mathrm{M}$ of forward and reverse primers, $130 \mu \mathrm{M}$ of each dNTP, $10 \mathrm{~mm}$ Tris-HCl (pH 8.3), $50 \mathrm{~mm} \mathrm{KCl,} 1.5 \mathrm{~mm}$ $\mathrm{MgCl}_{2}$ and $0.6 \mathrm{U}$ AmpliTaq Gold (Perkin-Elmer, Foster City, CA, USA). After an initial incubation at $95^{\circ} \mathrm{C}$ for $9 \mathrm{~min}$, amplification reactions were performed for 30 cycles each with denaturing at $95{ }^{\circ} \mathrm{C}$ for $30 \mathrm{~s}$, annealing for $1 \mathrm{~min}$ at 48-69 ${ }^{\circ} \mathrm{C}$ depending on the optimized annealing temperature of the primer used, and extension at $72{ }^{\circ} \mathrm{C}$ for $1 \mathrm{~min}$. This was followed by a final cycle at $72{ }^{\circ} \mathrm{C}$ for $5 \mathrm{~min}$. PCR products of 3-5 markers were combined and electrophoresed simultaneously on an ABI Prism 3100 DNA sequencer (Perkin-Elmer) and analysed using Genescan version 3.7 and Genotyper version 3.7 software (Perkin-Elmer).

\section{Linkage analysis}

Linkage analysis was performed using CriMap version 2.4 software (Green et al. 1990). Initially, the PREPARE option was used to scrutinize the data for problems with Mendelian inheritance and typing errors were rechecked within Genotyper and corrected where necessary. A two-point linkage analysis of all the markers was then computed based on an LOD score threshold of 3.0. Subsequently, markers belonging to the same linkage group were analysed using the BUILD option and the order of the different loci was 
examined with the FLIPS function. Map distances were derived based on the Kosambi mapping function.

\section{Comparative mapping with chicken}

Eight markers, which could be shown to be chicken-quail orthologues, were used as an aid to comparative mapping with chicken (Table 1). These consisted of three chicken microsatellites (ADL0037, ADL0142 and ADL0255 located on GGA1, GGA6 and GGA4, respectively) and five quail microsatellites (GUJ0001, GUJ0013, GUJ0023, GUJ0049 and GUJ0063) that cross-amplify chicken DNA and are orthologous to the chicken loci (Kayang et al. 2002). The quail cross-species microsatellites were genotyped in the East Lansing chicken reference family (Crittenden et al. 1993) and the data analysed by Map Manager Software (Manly 1993) to map the markers on chicken chromosomes. This enabled us to assign some of the quail linkage groups to chromosomes through comparative mapping with the chicken.

\section{Results and discussion}

Initially, all 103 microsatellite markers were tested in the $\mathrm{F}_{0}$ individuals and 12 markers were excluded as uninformative. A further 19 markers were removed from the analysis because of amplification problems or inconsistencies between parental and progeny alleles, thus leaving only 72 markers available for linkage analysis. The number of informative meioses in the mapping population of 497 quail varied from 30 to 754 . Fifty-eight markers were resolved into 12 autosomal linkage groups and a Z chromosomespecific linkage group (Fig. 1) while 14 markers were unlinked to any other marker. The linkage groups range from $8 \mathrm{cM}$ (two markers) to $206 \mathrm{cM}$ (16 markers) and the overall map coverage within linkage groups is $576 \mathrm{cM}$ with an average spacing of $10 \mathrm{cM}$ between loci.
Microsatellite markers are ideal tools for the development of genetic linkage maps as evidenced by the steadily growing number of genetic maps based on them. However, one major drawback is that they often tend to have a rather narrow phylogenetic applicability and will typically only work on very closely related species. In our attempt to use chicken microsatellites in quail only $5 \%(6 / 121)$ of the markers successfully amplified orthologous loci in quail and were found to contain microsatellite sequences (Inoue-Murayama et al. 2001). Therefore, the first step in a study that uses microsatellite markers is to locate useful markers in the study species. All but three of the microsatellites used in constructing these maps were quail-specific markers.

Of the three chicken markers that amplify orthologous loci in quail (Table 1), two (ADL0037 on GGA1 and ADL0142 on GGA6) were mapped to linkage groups CJA01 and CJA06 (Fig. 1), thus making it possible to assign these linkage groups to chromosomes 1 and 6 , respectively (Table 1). The third marker, ADL0255 (GGA4), was however not linked to any other marker in quail. In addition, marker GUJ0013 (linkage group CJA01) was mapped to chicken chromosome GGA1. Thus, the largest linkage group of 16 markers was assigned to chromosome 1 through two cross-species markers, ADL0037 and GUJ0013, of chicken and quail origins, respectively (Fig. 1). These two markers appeared to be very closely linked in quail with a recombination frequency of $1 \%$ (LOD score = 22.33). This tight linkage was also observed between the two markers when GUJ0013 was mapped in chicken using the East Lansing reference family, thus raising a suspicion that ADL0037 and GUJ0013 could be the same locus. However, a BLASTN search confirmed that they are in fact different. Similarly, GUJ0063 (linkage group CJA02), GUJ0049 (linkage group CJA05), GUJ0023 (linkage group CJA14) and GUJ0001 (linkage group CJA27) were mapped to chicken chromosomes GGA2, GGA5, GGA14 and GGA27, thereby enabling their respective linkage groups to

Table 1 Assignment of Japanese quail linkage groups to chromosomes through comparative mapping with chicken based on orthologous crossspecies markers.

\begin{tabular}{lllllll}
\hline $\begin{array}{l}\text { Orthologous } \\
\text { marker }\end{array}$ & $\begin{array}{l}\text { Accession } \\
\text { number } \\
\text { (chicken) }\end{array}$ & $\begin{array}{l}\text { Accession } \\
\text { number } \\
\text { (quail) }\end{array}$ & $\begin{array}{l}\text { Species of } \\
\text { origin }\end{array}$ & $\begin{array}{l}\text { Homology between } \\
\text { chicken and } \\
\text { quail 5' flank (\%) }\end{array}$ & $\begin{array}{l}\text { Chicken chromosome } \\
\text { location }\end{array}$ & $\begin{array}{l}\text { Quail linkage } \\
\text { group }\end{array}$ \\
\hline ADL0037 & L23912 & AF121113 & Chicken & $95(105 \mathrm{nt})$ & GGA1 & CJA01 \\
ADL0142 & G01567 & AF121114 & Chicken & $91(116 \mathrm{nt})$ & GGA6 & CJA06 \\
ADL0255 & G01675 & AB038402 & Chicken & $83(71 \mathrm{nt})$ & GGA4 & CJA27 \\
GUJ0001 $^{2}$ & AB063261 & AB035652 & Japanese quail & $84(176 \mathrm{nt})$ & GGA27 & CJA01 \\
GUJ0013 $^{2}$ & AB063262 & AB035823 & Japanese quail & $86(91 \mathrm{nt})$ & GGA1 & CJA14 \\
GUJ0023 $^{2}$ & AB063264 & AB035833 & Japanese quail & $80(152 \mathrm{nt})$ & GGA14 & CJA05 \\
GUJ0049 $^{2}$ & AB063268 & AB035859 & Japanese quail & $80(200 \mathrm{nt})$ & GGA5 & CJA02 \\
GUJ0063 $^{2}$ & AB063270 & AB063131 & Japanese quail & $86(138 \mathrm{nt})$ & GGA2 & \\
\hline
\end{tabular}

${ }^{1}$ Not assigned to any linkage group in Japanese quail.

${ }^{2}$ Japanese quail originated markers were assigned to chicken chromosomes in this study.

${ }^{3}$ Japanese quail linkage groups were assigned to quail chromosomes corresponding to the chicken chromosomes on which they were comparatively mapped. 


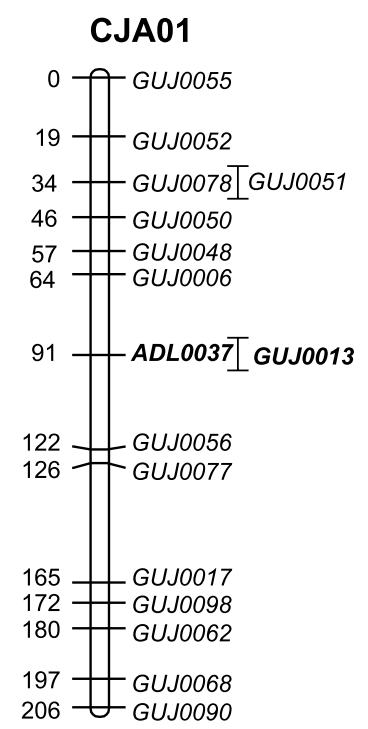

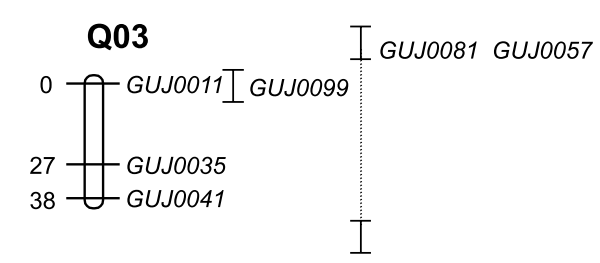

\section{Q04}

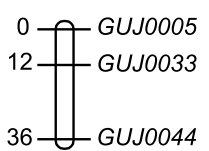

CJA05

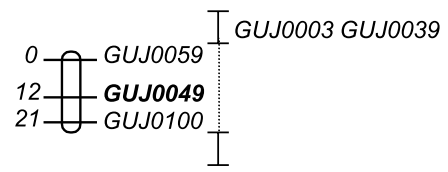

I GUJ0037 GUJ0067
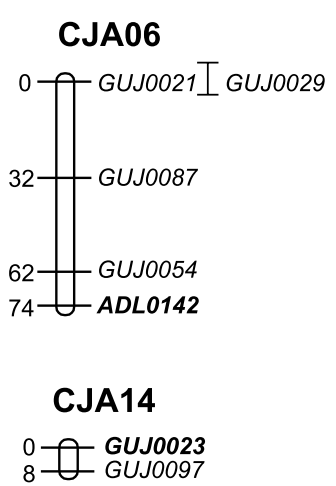

Q08

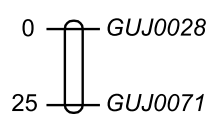

Q09

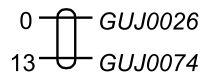

Q10

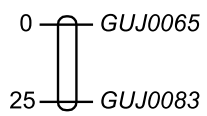

Q11

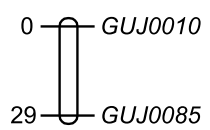

CJA27

9 -

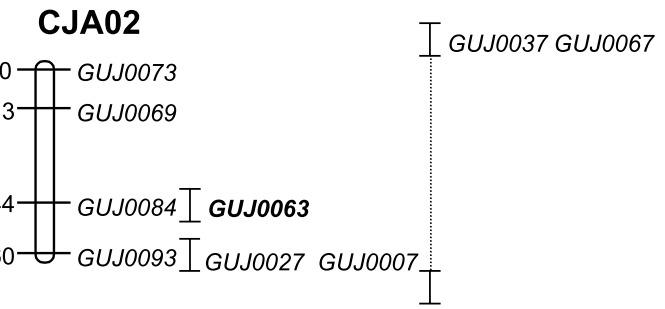

CJAZ

$0 \int_{32}^{0 \text { GUJ0040 }}$

Figure 1 Japanese quail microsatellite linkage map. The genetic linkage map based on an LOD score threshold of 3 is shown with the estimated Kosambi map distances in $\mathrm{cM}$ on the left. Loci on the framework are supported by odds $>3$ and the possible locations of loci not supported are indicated by an error bar. The autosomal linkage groups are presented as sex-averaged maps while the male-specific map is given for the Z-linkage group. Linkage groups that were assigned to chromosomes through comparative mapping with chicken are designated by CJA followed by a number corresponding to the chicken chromosomes on which they were comparatively mapped. Cross-species markers that were used to assign linkage groups to chromosomes through comparative mapping with chicken are shown in boldface type.

be assigned to these chromosomes in quail (Table 1). It is of interest to note that the microsatellite marker GUJ0001 was mapped to within $2.0 \mathrm{cM}$ of the growth hormone (GH) locus on the East Lansing linkage group E59 and could thus be a useful marker for this gene.

The assignment of the quail linkage groups to chromosomes through comparative mapping with chicken is supported by cytogenetic evidence of high quail-chicken chromosome correspondences. Recent cytogenetic studies based on banding patterns or chromosome painting using fluorescent in situ hybridization (FISH) have revealed highly conserved chromosome homology between chicken and quail, with only a few chromosome rearrangements (essentially pericentric inversions) observed in chromosomes 1, 2, 4 and 8 (Schmid et al. 2000; Shibusawa et al. 2001). In these studies, evidence of conserved synteny between chicken and quail was confirmed not only on the macrochromosomes but also on the microchromosomes as well. On the basis of such highly conserved syntenies, we considered it appropriate to assign quail linkage groups to chromosomes based on comparative mapping with chicken that utilized one or two orthologous cross-species markers per linkage group. However, because these assignments are based solely on assumptions of homology between markers and between chromosomes, they should be regarded as provisional.

Comparative mapping has proved to be a powerful tool for producing consensus genetic maps within- and betweenspecies (Groenen et al. 2000; Kurar et al. 2002), verification of quantitative trait loci (Sonstegard et al. 2000), identification of candidate genes for quantitative and complex traits (Cox et al. 2002) and for studying genome evolution (Burt et al. 1999). In this perspective, orthologous crossspecies markers serve as useful tools providing anchor points for comparisons across different species. However, the markers used in building this map are anonymous or type II markers (O'Brien 1991), and so to improve comparative mapping with the map-rich species, especially the chicken and human, it would be necessary to place a number of type I markers (genetic markers within or adjacent to known genes) on the map. 
The map coverage within the 13 linkage groups is $576 \mathrm{cM}$. Assuming $50 \mathrm{cM}$ for each of the 14 independent markers, the total map distance would be $1276 \mathrm{cM}$ $(576+50 \times 14)$, covering about a third of the quail genome of $3800 \mathrm{cM}$, estimated by comparison with chicken. Therefore, many more microsatellites are needed to obtain a better genome coverage. It has been estimated that about 200 markers evenly spaced at $20 \mathrm{cM}$ or less would be required to achieve a complete genome coverage suitable for full genome scanning projects (Groenen et al. 1998).

This map is the first microsatellite linkage map of the Japanese quail and is thus a major step towards the development of a quality molecular genetic map for this species. Recently, the first genetic map for quail was produced exclusively with AFLP markers (Roussot et al. 2003). Hence, it would be beneficial in the future to integrate the microsatellite and the AFLP maps in order to provide a powerful tool for the ongoing search for quantitative trait loci controlling egg production and fear-related behavioural traits in quail.

\section{Acknowledgements}

During this work, Boniface B. Kayang held successive postdoctoral research fellowships from the Gifu University (Japan) and from the Département de Génétique Animale (INRA, France). Quail reference families were kept under the supervision of David Gourichon and the care of Chantal Moussu at the Unité Expérimentale de Génétique Avicole (Nouzilly, France). All microsatellite typing work was carried out at the Gifu University with financial support of the 2001 grant from the same university.

\section{References}

Balthazart J., Baillien M., Charlier T.D., Cornil C.A. \& Ball G.F. (2003) The neuroendocrinology of reproductive behavior in Japanese quail. Domestic Animal Endocrinology 25, 69-82.

Baumgartner J. (1994) Japanese quail production, breeding and genetics. World's Poultry Science Journal 50, 227-35.

Burt D.W., Bruley C., Dunn I.C. et al. (1999) The dynamics of chromosome evolution in birds and mammals. Nature 402, 4113.

Burt D.W., Morrice D.R., Sewalem A., Smith J., Paton I.R., Smith E.J., Bentley J. \& Hocking P.M. (2003) Preliminary linkage map of the turkey (Meleagris gallopavo) based on microsatellite markers. Animal Genetics 34, 399-409.

Cox L.A., Birnbaum S. \& VandeBerg J.L. (2002) Identification of candidate genes regulating HDL cholesterol using a chromosomal region expression array. Genome Research 12, 1693-702.

Crawford R.D. (1990) Origin and history of poultry species. In: Poultry Breeding and Genetics (Ed. by R.D. Crawford), pp. 1-41. Elsevier, Amsterdam.

Crittenden L.B., Provencher L., Santangelo L., Levin I., Abplanalp H., Briles R.W., Briles W.E. \& Dodgson J.B. (1993) Characterization of a Red Jungle Fowl by White Leghorn backcross reference population for molecular mapping of the chicken genome. Poultry Science 72, 334-48.

Green P., Falls K. \& Crooks S. (1990) Documentation for CRI-MAP. Washington University School of Medicine, St Louis.

Groenen M.A.M., Crooijmans R.P.M.A., Veenendaal A., Cheng H.H., Siwek M. \& van der Poel J.J. (1998) A comprehensive microsatellite linkage map of the chicken genome. Genomics 49, 265-74.

Groenen M.A.M., Cheng H.H., Bumstead N. et al. (2000) A consensus linkage map of the chicken genome. Genome Research 10 , $137-47$.

Harry D.E., Zaitlin D., Marini P.J. \& Reed K.M. (2003) A firstgeneration map of the turkey genome. Genome 46, 914-24.

Howes J.R. (1964) Japanese quail as found in Japan. Quail Quarterly 1, 19-30.

Inoue-Murayama M., Kayang B.B., Kimura K. et al. (2001) Chicken microsatellite primers are not efficient markers for Japanese quail. Animal Genetics 32, 7-11.

Ito S., Kimura M. \& Isogai I. (1988a) A sex difference in recombination values between extended brown and phosphoglucose isomerase loci in Japanese quail. Japanese Journal of Zootechnical Science 59, 801-5.

Ito S., Kimura M. \& Isogai I. (1988b) Linkage between panda plumage and albumin loci in Japanese quail. Japanese Journal of Zootechnical Science 59, 822-4.

Jones R.B., Mills A.D. \& Faure J.M. (1991) Genetic and experiential manipulation of fear-related behavior in Japanese quail chicks (Coturnix coturnix japonica). Journal of Comparative Psychology 105, 15-24.

Kayang B.B., Inoue-Murayama M., Nomura A., Kimura K., Takahashi H., Mizutani M. \& Ito S. (2000) Fifty microsatellite markers for Japanese quail. The Journal of Heredity 91, 502-5.

Kayang B.B., Inoue-Murayama M., Hoshi T., Matsuo K., Takahashi H., Minezawa M., Mizutani M. \& Ito S. (2002) Microsatellite loci in Japanese quail and cross-species amplification in chicken and guinea fowl. Genetics Selection Evolution 34, 233-53.

Kurar E., Barendse W., Bottema C.D. et al. (2002) Consensus and comprehensive linkage maps of bovine chromosome 24. Animal Genetics 33, 460-3.

Le Douarin N.M., Catala M. \& Batini C. (1997) Embryonic neural chimeras in the study of vertebrate brain and head development. International Review of Cytology 175, 241-309.

Manly K.F. (1993) A Macintosh program for storage and analysis of experimental genetic mapping data. Mammalian Genome 4, 30313.

Mills A.D. \& Faure J.M. (1991) Divergent selection for duration of tonic immobility and social reinstatement behavior in Japanese quail (Coturnix coturnix japonica) chicks. Journal of Comparative Psychology 105, 25-38.

Mills A.D., Crawford L.L., Domjan M. \& Faure J.M. (1997) The behavior of the Japanese or domestic quail Coturnix japonica. Neuroscience Biobehavioral Reviews 21, 261-81.

Minvielle F. (1998) Genetics and breeding of Japanese quail for production around the world. In: Proceedings of the 6th Asian Pacific Poultry Congress, Nagoya, Japan, 4-7 June. pp. 122-7. Japan Poultry Science Association, Tsukuba.

Minvielle F., Coville J.L., Krupa A., Monvoisin J.L., Maeda Y. \& Okamoto S. (2000a) Genetic similarity and relationships of DNA fingerprints with performance and with heterosis in Japanese 
quail lines from two origins and under reciprocal recurrent or within-line selection for early egg production. Genetics Selection Evolution 32, 289-302.

Minvielle F., Ito S., Inoue-Murayama M., Mizutani M. \& Wakasugi N. (2000b) Genetic analyses of plumage color mutations on the $\mathrm{Z}$ chromosome of Japanese quail. The Journal of Heredity 91, 499-501.

Minvielle F., Monvoisin J.L., Costa J. \& Maeda Y. (2000c) Long-term egg production and heterosis in quail lines after within-line or reciprocal recurrent selection for high early egg production. British Poultry Science 41, 150-7.

O'Brien S.J. (1991) Mammalian genome mapping: lessons and prospects. Current Opinion in Genetics and Development 1, 105-11.

Pang S.W.Y., Ritland C., Carlson J.E. \& Cheng K.M. (1999) Japanese quail microsatellite loci amplified with chicken-specific primers. Animal Genetics 30, 195-9.

Primmer C.R., Raudsepp T., Chowdhary B.P., Møller A.P. \& Ellegren H. (1997) Low frequency of microsatellites in the avian genome. Genome Research 7, 471-82.

Ratnamohan N. (1985) The management of Japanese quail and their use in virological research: a review. Veterinary Research Communications 9, 1-14.

Roussot O., Feve K., Plisson-Petit F., Pitel F., Faure J.M., Beaumont C. \& Vignal A. (2003) AFLP linkage map of the Japanese quail Coturnix japonica. Genetics Selection Evolution 35, 559-72.
Schmid M., Nanda I., Guttenbach M. et al. (2000) First report on chicken genes and chromosomes 2000. Cytogenetics and Cell Genetics 90, 169-218.

Shibata T. \& Abe T. (1996) Linkage between the loci for serum albumin and vitamin D binding protein (GC) in the Japanese quail. Animal Genetics 27, 195-7.

Shibusawa M., Minai S., Nishida-Umehara C., Suzuki T., Mano T., Yamada K., Namikawa T. \& Matsuda Y. (2001) A comparative cytogenetic study of chromosome homology between chicken and Japanese quail. Cytogenetics and Cell Genetics 95, 103-9.

Smith J., Bruley C.K., Paton I.R. et al. (2000) Differences in gene density on chicken macrochromosomes and microchromosomes. Animal Genetics 31, 96-103.

Sonstegard T.S., Garrett W.M., Ashwell M.S., Bennett G.L., Kappes S.M. \& Van Tassell C.P. (2000) Comparative map alignment of BTA27 and HSA4 and 8 to identify conserved segments of genome containing fat deposition QTL. Mammalian Genome 11, $682-8$.

Stock A.D. \& Bunch T.D. (1982) The evolutionary implications of chromosome banding pattern homologies in the bird order Galliformes. Cytogenetics and Cell Genetics 34, 136-48.

Wakasugi N. (1984) Japanese quail. In: Evolution of Domesticated Animals (Ed. by I.L. Mason), pp. 319-21. Longman, London. 